Medical Scope Journal (MSJ). 2019;1(1):1-7

Available from: https://ejournal.unsrat.ac.id/index.php/msj

\title{
Kolangitis Akut dengan Komplikasi Perdarahan Saluran Cerna Bagian Atas dan Peningkatan Ca 19-9: Laporan Kasus
}

\author{
${ }^{1}$ Agnita Irawaty, ${ }^{2}$ Luciana Rotty \\ ${ }^{1}$ PPDS Ilmu Penyakit Dalam Fakultas Kedokteran Universitas Sam Ratulangi Manado \\ ${ }^{2}$ Bagian Ilmu Penyakit Dalam Fakultas Kedokteran Universitas Sam Ratulangi Manado \\ Email: agnita_irawaty@yahoo.co.id
}

\begin{abstract}
We reported a case of cholangitis in a 64-year-old-female associated with upper gastrointestinal bleeding. Diagnosis was confirmed by anamnesis, physical examination, and supportive investigation. This patient had a significant elevation of Ca 19-9 which often used to mark malignancy, especially in the pancreatic cancer. Albeit, in investigation we only found the obstruction of common bile duct stones. This case illustrates the fact that a markedly elevated CA 19-9 can be secondary to causes other than carcinoma.
\end{abstract}

Keywords: cholangitis, Ca 19-9

\begin{abstract}
Abstrak: Telah dilaporkan sebuah kasus kolangitis pada seorang perempuan berusia 64 tahun, yang juga mengalami komplikasi berupa perdarahan saluran cerna bagian atas. Diagnosis ditegakkan berdasarkan anamnesis, pemeriksaan fisik, dan pemeriksaan penunjang. Pasien ini mengalami peningkatan bermakna Ca 19-9 yang sering digunakan untuk menandai adanya penyakit keganasan terutama kanker pankreas, namun pada pemeriksaan penunjang hanya didapatkan adanya batu di duktus koledokus. Kasus ini mengilustrasikan fakta bahwa peningkatan bermakna CA 19-9 secara sekunder dapat disebabkan oleh sebab-sebab lain selain karsinoma.
\end{abstract}

Kata kunci: kolangitis, Ca 19-9

\section{PENDAHULUAN}

Kolangitis akut adalah kondisi sistemik yang berpotensi mengancam jiwa akibat infeksi saluran empedu, yang seharusnya steril, dan disebabkan karena obstruksi saluran bilier, paling sering karena sekunder oleh obstruksi sebagian atau komplit pada duktus bilier atau duktus hepatikus. Kondisi ini pertama kali dilaporkan pada tahun 1877 oleh Charcot dengan trias nyeri perut kanan atas, demam, dan jaundice (trias Charcot). Diagnosis ditegakkan berdasarkan pada karakteristik gejala klinis dan tanda tanda infeksi, laboratorium yang mendukung adanya infeksi dan sumbatan, serta pemeriksaan imaging yang mendukung adanya obstruksi bilier. Kondisi ini dapat ditangani dengan baik dengan terapi secara tepat, tetapi angka kematian dapat menjadi tinggi bila penanganan terlambat. ${ }^{1}$

Perdarahan saluran cerna bagian atas (SCBA) adalah kehilangan darah dari saluran cerna atas, di mana saja, mulai dari esofagus sampai dengan duodenum (batas anatomik di ligamentum Treitz), disertai manifestasi klinis berupa hematemesis, melena, hematoskezia atau kombinasi. Perdarahan ulkus peptikum merupakan penyebab tersering perdarahan SCBA, yaitu berkisar antara 31\% sampai 67\% dari semua kasus, diikuti oleh gastritis erosiva, perdarahan varikeal, esofagits, keganasan dan robekan Mallory-Weiss (MalloryWeiss tear). Respon inflamasi yang terjadi pada kolangitis dapat mengakibatkan terjadinya ulkus peptikum maupun gastritis erosiva. Hal tersebut dikarenakan pada kolangitis terjadi stres inflamasi yang dapat 
mengeluarkan mediator inflamasi seperti tumor necrosis factor (TNF), TNF receptor, interleukin (IL)-1, IL-6 dan IL-10. Mediator inflamasi ini menyebabkan ekspresi berlebihan dari sitokin yang menyebabkan kerusakan mukosa gaster. Inflamasi mukosa gaster bertanggung jawab terhadap terjadinya ulkus peptikum maupun gastritis erosif. $^{2}$

Antigen karbohidrat serum 19-9 (CA 19-9) sering digunakan untuk diagnosis dan penilaian prognosis dari neoplasma pankreatobilier. Kadar CA 19-9 >100 U/mL sering menandai adanya penyakit keganasan, terutama stadium awal kanker pankreas. $^{3}$

\section{LAPORAN KASUS}

Seorang pasien Ny. TA, 64 tahun, ibu rumah tangga, masuk ke RSUP Prof. Dr. R. D. Kandou Manado pada tanggal 16 Juni 2018 dengan keluhan muntah hitam sejak 1 minggu sebelum masuk rumah sakit (MRS). Muntah hitam sebanyak 5-6 kali, volume 100-150 cc setiap kali muntah. Nyeri perut kanan atas dirasakan sejak 2 bulan sebelum MRS yang memberat pada 1 minggu terakhir. Nyeri dirasakan hilang timbul, tidak dipengaruhi oleh makanan. Pasien mengeluh demam naik turun sejak 2 minggu sebelum MRS, demam turun bila minum obat penurun panas, kemudian timbul lagi. Pasien juga mengeluh mata dan badan kuning sejak 2 bulan sebelum MRS dan semakin kuning dalam 1 minggu terakhir. Berat badan pasien mengalami penurunan sebanyak $10 \mathrm{~kg}$ dalam 2 bulan.

Satu bulan yang lalu pasien pernah MRS dengan keluhan nyeri perut kanan atas dan kuning, dan pasien didiagnosis dengan batu empedu namun belum dilakukan operasi. Riwayat penyakit kuning, jantung, tekanan darah tinggi, ginjal, kencing manis, alergi, asam urat, disangkal oleh pasien. Riwayat penggunaan obatobatan penghilang nyeri/herbal, jamujamuan disangkal oleh pasien.

Pada pemeriksaan fisik didapatkan pasien tampak sakit berat, kesadaran kompos mentis, Glasgow Coma Scale (GCS) E4M6V5. Tekanan darah 100/70
mmHg; nadi $100 \mathrm{x} /$ menit; laju pernapasan 20x/menit; suhu badan $37^{\circ} \mathrm{C}$. Tinggi badan $160 \mathrm{~cm}$, berat badan $54 \mathrm{~kg}$, indeks massa tubuh (IMT) 21,09 kg/m2. Konjungtiva anemis, sclera ikterik. Lidah tidak kotor, tonsil tidak membesar, dan faring tidak hiperemis. Tidak ada pembesaran kelenjar getah bening. Pada pemeriksaan paru didapatkan simetris kiri dan kanan saat statis dan dinamis; stem fremitus kiri sama dengan kanan; perkusi sonor kiri sama dengan kanan; batas paru hati pada ruang antar iga VI kanan; suara nafas vesikuler, serta tidak ada ronki dan mengi. Pada pemeriksaan jantung didapatkan iktus kordis tidak tampak dan teraba di ruang antar iga V garis midklavikularis kiri; batas jantung kanan di ruang antar iga IV garis sternalis kanan; batas jantung kiri sesuai iktus kordis. Suara jantung pertama dan kedua normal, tidak terdengar bising. Pada pemeriksaan abdomen tampak distended, terdapat nyeri tekan perut kanan atas, pada perkusi didapatkan suara timpani, tidak terdapat shifting dullness. Ekstremitas tampak kuning, teraba hangat, tidak ada edema, tidak ada ruam maupun petekie.

Hasil pemeriksaan laboratorium di RSUP Prof. Dr. R. D. Kandou Manado sebagai berikut: $\mathrm{Hb}$ 9,5 g/dL; MCH 37,7 pg; MCHC 38,9 g/dl; MCV 97,0 fL; leukosit $18.400 / \mathrm{mm} 3$; hematokrit 24,4\%; trombosit 332.000/mm3; SGOT $147 \mathrm{U} / \mathrm{L}$; SGPT $120 \mathrm{U} / \mathrm{L}$; ureum $37 \mathrm{mg} / \mathrm{dL}$; kreatinin 0,5 mg/dL; gula darah sewaktu (GDS) 154 mg/dL; Natrium (Na) 124 mEq/L; Kalium (K) 3,1 mEq/L; Chlorida (Cl) $92 \mathrm{mEq} / \mathrm{L}$.

Berdasarkan hasil anamnesis, pemeriksaan fisik, laboratorium dan pemeriksaan penunjang maka dibuat diagnosis kerja yaitu hematemesis ec suspek ulkus peptikum berdarah, dengan diagnosis banding gastritis erosiva, kolangitis ec koledokolitiasis, anemia ec perdarahan saluran cerna, hiponatremia. Pasien diberikan terapi infus $\mathrm{NaCl}$ 0,9\% dan aminofusin hepar (3:1) 24 tetes per menit, esomeprazole $80 \mathrm{mg}$ bolus intravena dilanjutkan dengan esomeprazole $200 \mathrm{mg}$ dalam $\mathrm{NaCl}$ $0,9 \% 500$ cc 7 tetes per menit, cefotaxime 3x2 gram (intra-vena), metronidazole 1000 
mg loading lalu selanjutnya $3 \times 500 \mathrm{mg}$ (intravena), asam tranexamat $3 \times 500 \mathrm{mg}$, sucralfat $3 \times 15 \mathrm{ml}$, ondansetron $3 \times 8 \mathrm{mg}$ (intravena). Pasien juga ditransfusi packed red blood cells (PRC) dan sementara dipuasakan dan dipasang nasogastric tube (NGT). Pasien direncanakan untuk dilakukan Magnetic Resonance Cholangiopancreatography (MRCP).

Pada hari kedua perawatan pasien masih mengeluh nyeri perut. Tekanan darah 100/60 mmHg, nadi $106 \mathrm{x} /$ menit, regular, isi cukup; pernapasan $20 \mathrm{x} /$ menit; suhu badan $37,3^{\circ} \mathrm{C}$. Produksi NGT masih hitam, sebanyak 500 cc dalam 24 jam. Pemeriksaan fisik didapatkan kesadaran kompos mentis, GCS 15 (E4M6V5); konjungtiva anemis, sklera ikterik. Terapi dilanjutkan.

Pada hari ketiga perawatan pasien masih mengeluh mual, nyeri perut berkurang. Tekanan darah 110/70 mmHg, nadi $86 \mathrm{x} / \mathrm{menit}$, regular, isi cukup; pernafasan 20 x/menit; suhu badan 36,7 C. Produksi NGT masih hitam, sebanyak 380 cc dalam 24 jam. Pemeriksaan fisik didapatkan kesadaran kompos mentis, GCS 15 (E4M6V5); konjungtiva anemis, sclera ikterik. Terapi dilanjutkan.

Hasil pemeriksaan laboratorium tanggal 18 Juni 2018 di RSUP Prof. Dr. R. D. Kandou Manado sebagai berikut: Hb 8,3 $\mathrm{g} / \mathrm{dL}$; leukosit 19.400/mm3; hematokrit 21,4\%; trombosit 280.000/mm3; $\mathrm{MCH}$ 38,2 pg; MCHC 39,1 g/dl; MCV 97,9 fL; SGOT 113 U/L; SGPT 96 U/L; gamma GT (GGT) $273 \mathrm{u} / \mathrm{l}$; bilirubin total 26,43 mg/dl; bilirubin direk 21,8 mg/dl; alkalin fosfatase $295 \mathrm{u} / \mathrm{l}$; anti HCV kualitatif nonreaktif; HbsAg Elisa nonreaktif; anti HIV Elisa nonreaktif; CA 19-9 >1000 U/ml; PT pasien 15,1 detik, kontrol 13,7 detik; INR 1,15 detik; APTT pasien 38,6 detik; APTT control 33,1 detik.

Pada hari keempat perawatan pasien masih mengeluh mual. Tekanan darah 110/70 mmHg, nadi $80 \mathrm{x} / \mathrm{menit}$, regular, isi cukup; pernapasan $20 \mathrm{x} /$ menit; suhu badan $36,8^{\circ}$ C. Produksi NGT masih hitam, sebanyak 250 cc dalam 24 jam. Pemeriksaan fisik didapatkan kesadaran kompos mentis, GCS 15 (E4M6V5); konjungtiva anemis, sklera ikterik. Terapi dilanjutkan dan dilakukan transfusi PRC.

Pada hari kelima perawatan, pasien dilakukan pemeriksaan laboratorium dengan hasil sebagai berikut: $\mathrm{Hb} 10,7 \mathrm{~g} / \mathrm{dL}$ (naik); leukosit 15.400 /mm3 (turun); hematokrit 28,2\%; trombosit $241.000 / \mathrm{mm} 3$; MCH 34,4 pg; MCHC 38,0 g/dl; MCV 90,6 fL; natrium $133 \mathrm{mEq} / \mathrm{L}$ (naik); kalium 3,4 (naik) mEq/L; klorida $104 \mathrm{mEq} / \mathrm{L}$.

Hasil Magnetic Resonance Cholangiopancreatography (MRCP) memperlihatkan pelebaran duktus biler proksimal sampai ke intrahepatik ec batu distal common bile duct (CBD) ukuran $1,4 \mathrm{~cm} \quad \mathrm{x} \quad 1,4 \mathrm{~cm}$ (Gambar 1 dan 2).

Pada hari ke enam, kondisi pasien sudah memperlihatkan perbaikan, tidak mual, tidak muntah, dan tidak demam, tekanan darah 120/80 mmHg, nadi 80 $\mathrm{x} /$ menit, regular, isi cukup; pernapasan 20 $\mathrm{x} /$ menit; suhu badan $36,3^{\circ} \mathrm{C}$. NGT sudah tidak produksi. Pada pemeriksaan fisik didapatkan kesadaran kompos mentis, GCS 15 (E4M6V5); sklera ikterik. Pasien dikonsulkan ke Bagian Bedah, dan direncanakan untuk operasi eksplorasi CBD.

\section{BAHASAN}

Kolangitis akut ialah kondisi sistemik yang berpotensi mengancam jiwa akibat infeksi saluran empedu, yang seharusnya steril, dan obstruksi bilier. Kondisi ini dapat diatasi dengan penanganan secara tepat, tetapi angka kematian dapat menjadi tinggi pada penanganan yang terlambat. Bila kolangitis akut tidak diketahui lebih cepat dan diterapi dengan tidak tepat, dapat terjadi systemic inflammatory response syndrome (SIRS), sepsis, dan kematian dengan cepat. Kolangitis akut berat mempunyai angka mortalitas antara 11\% hingga 27\% pada 1990an. ${ }^{1,4}$

Prevalensi koledokolitiasis bervariasi pada etnis yang berbeda. Batu empedu ditemukan pada $10-15 \%$ populasi kulit putih di Amerika Serikat. Prevalensi pada penduduk asli Amerika dan Hispanik jauh lebih banyak (60-70\%) tetapi kurang sering pada penduduk Asia dan Afro Amerika. ${ }^{2}$ 


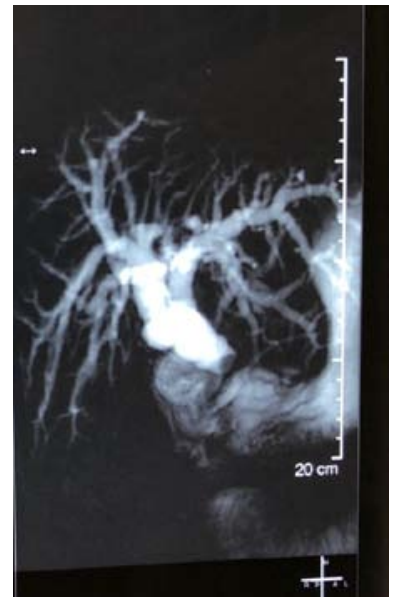

Gambar 1. Kolestatik ekstra dan intrahepatik ec batu distal CBD

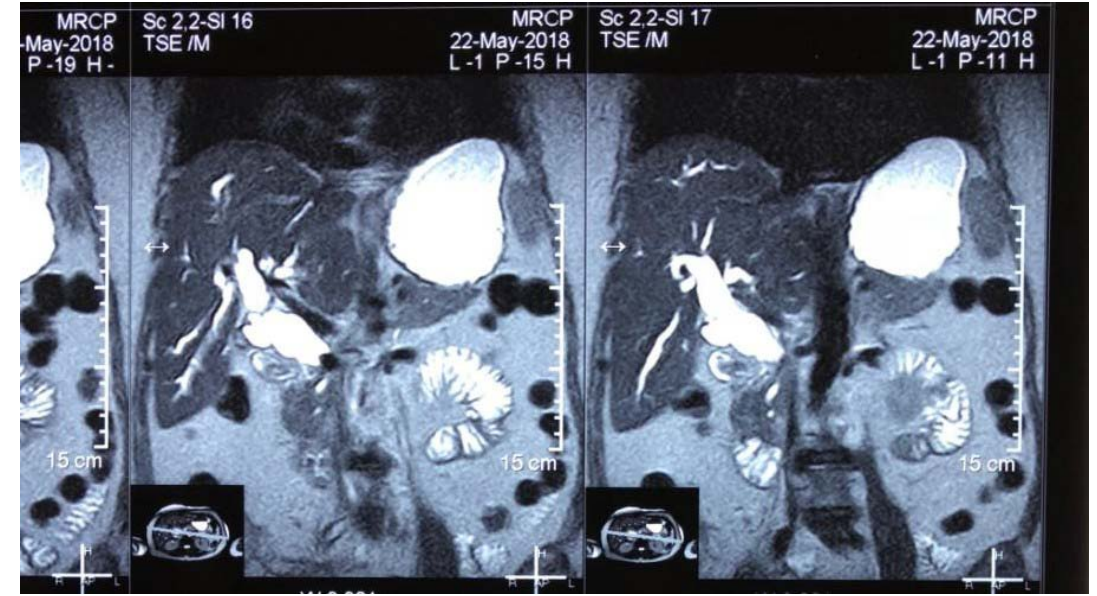

Gambar 2. Pelebaran duktus bilier intrahepatik. Pankreas: Parenkim normal, tidak terlihat massa, ductus pankreatikus tidak melebar. Terlihat adanya void signal berukuran $1,4 \mathrm{~cm} \times 1,4 \mathrm{~cm} \times 1,4 \mathrm{~cm}$ di distal CBD, menyebabkan pelebaran pada duktus proksimalis sampai duktus bilier intrahepatik
Banyak pasien masuk rumah sakit dengan penyakit batu empedu dan 6-9\% nya dengan komplikasi kolangitis akut. ${ }^{3}$ Prevalensi pada laki-laki dan perempuan ditemukan sama banyak. Rerata usia pasien dengan kolangitis akut ialah 50-60 tahun. ${ }^{3}$ Pada kasus ini, pasien seorang perempuan berusia 64 tahun.

Penyebab tersering dari obstruksi bilier ialah koledokolitiasis. Penyebab obstruksi lainnya ialah struktur jinak atau ganas dari duktus biliaris atau duktus hepatikus, kanker pankreas, adenoma atau kanker ampula, tumor atau metastasis porta hepatis, stenosis obstruksi bilier (akibat pembentukan biofilm mikroba, deposisi sludge bilier, dan refluks duodenal yang berisi makanan), sklerosing kolangitis primer, deposisi amiloid pada sistem bilier, ${ }^{4}$ sindrom Mirizzi (batu empedu terimpaksi dalam duktus sistikus atau leher kandung empedu menyebabkan kompresi duktus biliaris komunis atau duktus hepatikus komunis), sindrom Lemmel (divertikulum ampula menyebabkan obstruksi bilier distal), investasi duktus biliaris oleh cacing gelang (Ascaris lumbricoides) atau cacing pita (Taenia saginata), ${ }^{5}$ kolangiopati AIDS, dan striktur anastomosis bilioenterik. Koledokel dan duktus biliaris sempit merupakan faktor risiko lainnya untuk kolangitis akut. Post Endoscopic Retrograde Cholangio- pancreatography (ERCP) kolangitis akut dapat terjadi pada $0,5-2,4 \%$ kasus. ${ }^{6}$ Pada kasus ini, penyebab terjadinya obstruksi bilier dikarenakan adanya koledokolitiasis.

Obstruksi bilier memegang peranan penting dalam terjadinya kolangitis akut. Patofisiologi kolangitis akut pada obstruksi bilier ialah empedu menjadi stagnan dalam sistem bilier, tekanan intraduktal meningkat, tight junction antara kolangiosit melebar, malfungsi sel Kupffer, dan produksi IgA menurun. ${ }^{7}$ Tekanan koledokal berperan penting dalam patogenesis kolangitis akut. Tekanan duktus biliaris normal ialah 7-14 $\mathrm{cm} \mathrm{H}_{2} \mathrm{O}$. Ketika tekanan intraduktal melebihi $25 \mathrm{~cm} \mathrm{H}_{2} \mathrm{O}$, dapat terjadi refluks kolangiovenous dan kolangiolimfatik, yang menyebabkan bakteriemia dan endotoksinemia. ${ }^{8}$ Selain itu, pelepasan mediator inflamasi sistemik seperti TNF, reseptor terlarut TNF, interleukin (IL)-1, IL-16, dan IL-10 menyebabkan gangguan hemodinamik berat. $^{8}$

Diagnosis banding dari kolangitis akut yaitu kolesistitis akut, sirosis hati, hepatitis akut, abses hati, syok septik, divertikulitis sisi kanan, dan pielonefritis. ${ }^{9}$

Pemeriksaan darah yang berguna pada kolangitis akut ialah yang menandai adanya inflamasi (meningkatnya leukosit dan/atau meningkatnya $C$-reactive protein/CRP) dan bukti obstruksi komplit atau parsial duktus biliaris (meningkatnya bilirubin, enzim 
hepar dan bilier, seperti aspartat alanin aminotransferase, aspartat aminotransferase, alkalin fosfatase dan GGT). Kultur darah sebaiknya dilakukan secepat mungkin. Guideline TG13 juga merekomendasikan pengambilan sampel empedu selama prosedur drainase. Kultur empedu dapat positif pada 59-93\% dari kasus kolangitis akut. Patogen yang paling sering diisolasi dari darah pada kasus kolangitis akut ialah organisme coliform, seperti Escherechia coli (25-50\%), Klebsiella species (15-20\%), Enterococcus species (10-20\%), dan Enterobacter species (5$10 \%) .{ }^{9}$ Pada pasien ini hasil kultur darah belum ada sampai saat pasien rawat jalan.

Studi pencitraan dapat terdiri dari USG abdomen, computed tomography (CT) reguler atau helikal, MRCP, dan USG endoskopik/Endoscopic Ultrasound (EUS). CT non kontras lebih sensitif daripada USG abdomen dalam mendeteksi batu duktus biliaris komunis. Di antara teknik-teknik tersebut, MRCP (akurasi 82,2\% dalam mendeteksi koledokolitiasis) dan EUS (akurasi 96,9\% dalam mendeteksi koledokolitiasis) merupakan modalitas paling sensitif, yang dapat mendeteksi tingkat dan penyebab obstruksi bilier. USG transabdominal dapat mendeteksi koledokolitiasis pada $30 \%$ kasus, dan CT pada $42 \%$ kasus. Walaupun MRCP semakin sering digunakan pada kasus kolangitis akut, sensitivitasnya untuk mendeteksi batu kurang dari $6 \mathrm{~mm}$ rendah. ${ }^{10}$ Pada pasien ini dilakukan pemeriksaan imaging dengan MRCP.

Pada tahun 2012, TG13, guideline Tokyo yang baru untuk diagnosis kolangitis akut dikeluarkan, ${ }^{10}$ dengan kriteria sebagai berikut: 1) inflamasi sistemik: A-1: demam (suhu tubuh $>38^{\circ} \mathrm{C}$ dan/atau menggigil; A2: data laboratorium: bukti respons inflamasi - jumlah sel leukosit (WBC) $<4.000 / \mathrm{cm}^{3}$ atau $>10.000 / \mathrm{cm}^{3}$, CRP $\geq 1$ mg/dL; dan 2) Kolestasis: B-1: Jaundice bilirubin tota $2 \mathrm{mg} / \mathrm{dL} ; \quad \mathrm{B} \quad-2$ : data laboratorium: tes fungsi hati abnormal. Alkalin fosfatase (IU) $>1,5 \mathrm{x}$ batas atas normal; gamma GT (IU) $>1,5 x$ batas atas normal; aspartat aminotransferase (IU) $>1,5 \mathrm{x}$ batas atas normal; alanin amino- transferase (IU) $>1,5 x$ batas atas normal. Pencitraan: C-1: pelebaran bilier; C-2: bukti etiologi pada pencitraan (striktur, batu, dll.). Diagnosis suspek bila didapatkan satu kriteria pada A dan satu kriteria pada B atau $C$ sedangkan diagnosis definitif bila didapatkan satu kriteria pada A, satu kriteria pada B dan satu kriteria pada C. ${ }^{10}$

Terdapat dua tanda klinis untuk menentukan beratnya kolangitis yaitu respon terhadap terapi awal dan disfungsi organ. Kolangitis akut ringan (grade 1) ditandai sebagai kolangitis akut yang memberikan respon pada terapi medis awal. Kolangitis akut sedang (grade 2) didefinisikan sebagai kolangitis akut yang tidak memberikan respon pada terapi medis awal tetapi tidak terjadi disfungsi organ. Kolangitis akut berat (grade 3) adalah kolangitis akut yang tidak memberikan respon pada terapi medis awal dan terdapat kegagalan organ: sistem kardiovaskular (hipotensi yang memerlukan dopamin $\geq 5$ $\mu \mathrm{g} / \mathrm{kg} / \mathrm{menit}$ atau dosis berapapun dari dobutamin), sistem saraf pusat (penurunan kesadaran), sistem respirasi (PaO2:FiO2 rasio $<300$ ), ginjal (serum kreatinin $>176$ $\mu \mathrm{mol} / \mathrm{L}$ ), hepar (PT-INR >1,5) dan sistem hematologi (platelet $<100 \times 10^{9} / \mathrm{L}$ ). ${ }^{11}$ Kasus ini termasuk dalam kolangitis grade 1, karena pasien mengalami perbaikan secara klinis maupun laboratorium.

Kolangitis akut harus ditangani sebagai kondisi emergensi karena kolangitis akut disebabkan oleh infeksi dan obstruksi saluran bilier, sehingga kedua aspek tersebut perlu ditangani. Cairan intravena dan antibiotik harus diberikan secepat mungkin. Karena tekanan intraduktal meningkat, maka sekresi antibiotik dari saluran bilier terhambat, sehingga drainase bilier merupakan langkah selanjutnya dari tatalaksana kolangitis akut.

Pemberian antibiotik empirik harus melingkupi Gram negatif dan organisme anaerob. Pilihan awal sebaiknya diberikan piperacillin-tazobactam, ticarcillin-clavulanate, ceftriaxone + metronidazole, atau ampicillin-sulbactam. Bila pasien sensitif terhadap penisilin, maka ciprofloxacin + metronidazole, carbapenem, atau gentamicin 
+ metronidazole merupakan pilihan yang baik. Antibiotik tersebut harus dievaluasi lebih lanjut dan disesuaikan menurut hasil kultur darah. Kultur darah positif dalam 21$71 \%$ kasus kolangitis akut. Dosis antibiotik harus disesuaikan menurut fungsi ginjal dan hepar. Idealnya, antibiotik harus diberikan selama 7-10 hari. ${ }^{12}$ Pada kasus ini diberikan terapi dengan antibiotik cefotaxime 2 gram setiap 8 jam selama 6 hari.

Tindakan Endoscopic Retrograde Cholangiopancreatography (ERCP) merupakan pilihan prosedur untuk dekompresi bilier dan drainase. Stent plastik lebih mudah dimasukkan dan diambil, serta lebih cost effective daripada stent metal. Stent plastik juga kurang memungkinkan untuk terjadi pertumbuhan tumor, yang dapat menyebabkan obstruksi stent, tetapi lebih memungkinkan untuk tersumbat oleh biofilm dan sludge dibandingkan dengan stent metal. Percutaneus Tranhepatic Biliary Drainage (PTBD) secara umum dilakukan bila ERCP gagal atau bila pasien mempunyai banyak komorbiditas dan bukan merupakan kandidat yang baik untuk ERCP. PTBD dapat menyebabkan komplikasi yang lebih serius, seperti peritonitis bilier, dan perdarahan intraperitoneal. ${ }^{10}$

Drainase bilier Endoscopic Ultrasound (EUS-guided) dapat dilakukan bila ERCP gagal akibat berbagai alasan, seperti obstruksi ampula, obstruksi outlet gaster, atau anatomi yang berubah akibat operasi (pembedahan Roux-en-Y, gastric bypass, dll.), dan duktus biliaris intrahepatal tidak melebar. Koledokoduodenostomi EUSguided darurat dengan menggunakan stent metal merupakan salah satu pilihan dalam kasus kolangitis akut, terutama pada layanan tersier. Drainase secara operasi dilakukan bila modalitas drainase bilier lain dikontra-indikasikan atau gagal. Saat ini jarang dilakukan karena angka kematian yang tinggi $20-60 \%$. Untuk menghindari perawatan yang lama, koledokotomi dengan drainase T-Tube tanpa koledokolitotomi direkomendasikan. ${ }^{11,13}$ Pada kasus ini, pasien dikonsulkan ke bagian bedah untuk tindakan operasi explorasi CBD.

Perdarahan saluran cerna bagian atas
(SCBA) adalah kehilangan darah dari saluran cerna atas, di mana saja, mulai dari esofagus sampai dengan duodenum (dengan batas anatomik di ligamentum Treitz), dengan manifestasi klinis berupa hematemesis, melena, hematoskezia atau kombinasi. Perdarahan ulkus peptikum merupakan penyebab tersering perdarahan SCBA, berkisar antara 31\% sampai 67\% dari semua kasus, diikuti oleh gastritis erosif, perdarahan variceal, esofagits, keganasan dan robekan Mallory-Weiss.

Respon inflamasi yang terjadi pada kolangitis dapat mengakibatkan terjadinya ulkus peptikum maupun gastritis erosive. Hal tersebut dikarenakan pada kolangitis terjadi stres inflamasi yang dapat memicu pengeluaran mediator inflamasi seperti TNF, TNF receptor, IL-1, IL-6, dan IL-10. Faktor ini menyebabkan overekspresi sitokin yang berakibat kerusakan mukosa gaster. Selanjutnya inflamasi mukosa gaster bertanggung jawab terhadap terjadinya ulkus peptikum. ${ }^{8,12}$

Antigen karbohidrat serum 19-9 (CA 19-9) sering digunakan untuk diagnosis dan penilaian prognosis dari neoplasma pankreatobilier. Kadar CA 19-9 >100 U/mL sering menandai adanya penyakit keganasan, terutama sadium awal kanker pankreas. Spesifitas dari kadar CA 19-9 >1000 U/mL untuk kanker pankreas ialah 99\%. Namun, kadar CA 19-9 setinggi $>1000 \mathrm{U} / \mathrm{mL}$ sering juga ditemukan pada beberapa penyakit jinak, seperti batu duktus biliaris komunis, kolangitis akut, pankreatitis akut, diabetes, dan sirosis hepatis. ${ }^{10}$

Alasan peningkatan CA 19-9 pada kolangitis akut yang sebenarnya masih belum jelas. Beberapa mekanisme telah dikemukakan, yaitu: 1) kebocoran CA 19-9 dari empedu ke sirkulasi darah akibat obstruksi traktus biliaris, 2) produksi CA 19-9 oleh sel ductus biliaris teriritasi yang terkena peningkatan tekanan bilier dapat meningkat, 3) peningkatan produksi CA 19-9 pada epitel ductus biliaris dan mukosa kandung empedu yang diinduksi oleh proses inflamasi, 4) sitokin inflamasi yang diproduksi pada sepsis akibat kolangitis mungkin juga memberikan kontribusi. ${ }^{10}$ 
Walaupun peningkatan kadar CA 19-9 terjadi pada banyak pasien dengan karsinoma pankreas, hal ini juga dapat terjadi pada pasien dengan keganasan ekstrahepatik dan kolangitis akut. Hal ini mungkin tidak dapat digunakan sebagai kriteria diagnostik yang efektif. CA 19-9 dikatakan tidak dapat digunakan untuk membedakan antara jaundice ekstrahepatik ganas dan jinak. Oleh karena itu, peningkatan kadar CA 19-9 harus diinterpretasikan secara hati-hati pada pasien dengan jaundice obstruksi, kecuali bila kadar yang tinggi menetap setelah obstruksi dihilangkan.

Pada kasus ini, kadar CA 19-9 yang tinggi terutama disebabkan oleh obstruksi batu duktus koledokus. Peningkatan bilirubin total, ALP, dan GGT serum juga menandai adanya batu bilier dan obstruksi.

\section{SIMPULAN}

Telah dilaporkan kasus kolangitis pada seorang perempuan usia 64 tahun yang juga mengalami komplikasi berupa perdarahan saluran cerna bagian atas. Diagnosis ditegakkan berdasarkan anamnesis, pemeriksaan fisik, dan pemeriksaan penunjang. Pasien ini mengalami peningkatan bermakna Ca 19-9 yang sering digunakan untuk menandai adanya penyakit keganasan terutama kanker pankreas, namun pada pemeriksaan penunjang hanya didapatkan adanya batu di duktus koledokus.

Kasus ini mengilustrasikan fakta bahwa peningkatan bermakna CA 19-9 secara sekunder dapat disebabkan oleh sebab-sebab lain selain karsinoma.

\section{DAFTAR PUSTAKA}

1. Lan CW, Christophi C, Muralidharan V. Acute cholangitis: Current concepts. ANZ J Surg. 2017;87(7-8):554-9.

2. Watanabe $T$, Higuchi $K$, Tanigawa $T$, Tominaga K, Fujiwara Y, Arakawa T. Mechanisms of peptic ulcer recur- rence: role of inflammation. InflammoPharmacology. 2002;10(4-6):291-302.

3. Steinberg W. The clinical utility of the CA 199 tumor-associated antigen. Am J Gastroenterol. 1990;85:350-5.

4. Andrew DJ, Johnson SE. Acute suppurative cholangitis, a medical and surgical emergency. Am. J. Gastroenterol. 1970; 54:141-54.

5. Shaffer EA. Gallstone disease: Epidemiology of gallbladder stone disease. Best Pract Res Clin Gastroenterol. 2006;20:98196.

6. What if it's acute cholangitis? Drug Ther Bull 2005;43:62-4.

7. Clough J, Shah R. Primary amyloidosis presenting as common bile duct obstruction with cholangitis. ACG Case Rep J. 2015;2:107-9.

8. Mosler P. Management of acute cholangitis. Gastroenterol Hepatol (NY). 2011;7:121-3.

9. Sung JY, Costerton JW, Shaffer EA. Defense system in the biliary tract against bacterial infection. Dig Dis Sci 1992; 37:689-96.

10. Buyukasik K, Toros AB, Bektas H, Ari A, Deniz MM. Diagnostic and therapeutic value of ERCP in acute cholangitis. ISRN Gastroenterol. 2013;2013:191729.

11. Kinney TP. Management of ascending cholangitis. Gastrointest Endosc Clin N Am. 2007;17:289-306.

12. Wada K, Takada T, Kawarada Y, Nimura Y, Miura F, Yoshida M, et al. Diagnostic criteria and severity assessment of acute cholangitis: Tokyo Guidelines. J. Hepatobiliary Pancreat. Surg. 2007; 14:52

13. Kiriyama S, Takada T, Strasberg SM, Solomkin JS, Mayumi T, Pitt HA, et al. Tokyo Guidelines Revision Committee. New diagnostic criteria and severity assessment of acute cholangitis in revised Tokyo Guidelines. J Hepatobiliary Pancreat Sci. 2012;19:548-56. 